\title{
LUT
}

University

No manager is an island: culture in sensemaking of business networking

Ivanova-Gongne Maria, Torkkeli Lasse

This is a Final draft version of a publication

published by Emerald Publishing

in Journal of Business and Industrial Marketing

DOI: $10.1108 / J B I M-07-2016-0154$

Copyright of the original publication: (c) Emerald Publishing 2018

Please cite the publication as follows:

Ivanova-Gongne, M., Torkkeli, L. (2018). No manager is an island: culture in sensemaking of business networking. Journal of Business and Industrial Marketing, vol. 33, issue 5. pp. 638-650.

DOI: 10.1108/JBIM-07-2016-0154

This is a parallel published version of an original publication.

This version can differ from the original published article. 
Cite as: Ivanova-Gongne, M. \& Torkkeli, L. (2018). No Manager is an Island: Culture in

Sensemaking of Business Networking, Journal of Business and Industrial Marketing, 33(5), 638-

650. DOI: https://doi.org/10.1108/JBIM-07-2016-0154

\section{No Manager Is an Island: Culture in Sensemaking of Business Networking}

\section{Introduction}

Since "No business is an island" (Håkansson and Snehota, 1989; 2006), the success or failure of companies today tends to be determined by their business relationships (Parker, 2008; Pittaway et al., 2004; Watson, 2007). These relationships form dyads, a series of which creates a business network (Håkansson, 1982; Håkansson and Snehota, 1995; Turnbull et al., 1996). Business nowadays is also increasingly conducted across national and industrial boundaries (e.g., Casson, 2013), which also requires that managers increasingly interact with other managers of different cultural backgrounds.

However, studies investigating business networking so far are still limited, as they tend to be based on concepts from the developed world (see Lowe et al., 2008; Gao et al., 2012). This is the case even though many emerging markets' business cultures operate under distinct cultural concepts related to business networking that would lead one to assume dissimilarities (e.g., Jansson et al., 2007; Ibeh et al., 2012; Michailova and Worm, 2003). Most existing studies also ignore the fact that the term business networking may mean different things to individual managers across cultures, and instead adhere to the prevalent academic view of business networks as interlinked sets of dyadic business relationships that comprise self-organizing systems (e.g., Wilkinson \& Young, 2002; Ritter et al., 2004; Möller \& Rajala, 2007). Thus, there is still a need to understand and clarify how individual views on networking are formed (see Henneberg et al., 2010; Mattsson et al., 2015) from a cultural perspective.

The cultural perspective in networking could be illustrated through sensemaking. Research has suggested that managerial sensemaking can facilitate business networking (Henneberg et al., 2010; Mattsson et al., 2015; Rasmussen and Madsen, 2001). Still, the ways in which the process of business networking is traditionally conceptualized in literature are done mostly on an organizational level (Henneberg et al., 2010). However, literature on the ways in which different individuals understand the process is still developing and mostly focuses on the structure of networks, namely network pictures (Laari-Salmela et al., 2015). Over the past decade, businessnetwork literature has called for "viewing the role of the manager as some sort of author" (Lowe et al., 2008, p. 304) and has been generating business-network knowledge from managerial sensemaking by looking at cognitive representations (Mattsson et al., 2015). However, the role of cultural contexts, in which these representations are deeply embedded, is often disregarded. 
To respond to these gaps in the literature, our aim in this study is to investigate the sensemaking by which individual managers with different cultural backgrounds understand business networking. Thus, the present study is of a phenomenological nature, in which the aim is not to seek an absolute truth or extensive generalizations, but rather an effort to understand how different cultural contexts under which managers operate can contribute to problematizing the extant literature on business networking.

One fruitful empirical arena in which to understand the cultural aspects of networking is among managers of international small- and medium-size enterprises (SMEs) in the context of FinnishRussian business relationships. The two cultures represent developed and emerging-market contexts, respectively, a relevant perspective for two reasons: First, they differ in the composition of business networks and inter-organizational ties (McDermott and Corredoira, 2010), and second, inherent in the Russian business culture are elements that conceptually distinguish its business-relationship environment from that of Western Europe (Michailova and Worm, 2003).

Moreover, networking across cultures is especially critical for SMEs (Terziovski, 2003). SMEs generally are characterized by a simple structure (Bouchard and Basso, 2011) in which the importance of individual managers is highlighted and core actors are individuals (e.g., Davidsson and Honig, 2003; Hill and Tiu Wright, 2001). For SMEs, individual managers who can make sense of and seize opportunities play a major role in the international context (Crick \& Spence, 2005), and networking and business relationships are essential to SMEs for cultivating business relationships across borders (e.g., Coviello and Munro, 1995; Torkkeli et al., 2012). The underlying, established dynamic is that SMEs are resource-constrained due to their small size (Knight and Cavusgil, 2004), and networks may enable them to overcome such constraints and enter foreign markets (Sasi and Arenius, 2008).

Thus, any differences in sensemaking based on the cultures of the managers involved in such business relationships are accentuated in SMEs. However, extant literature has not assessed these differences in detail until now. Problematizing (see Alvesson and Sandberg, 2011) some of the assumptions about business networks and networking in extant literature can yield valuable insights for business-to-business marketing literature. The remainder of this paper is constructed as follows. First, we examine the theoretical background and existing research on business networking in cross-cultural business relationships. Second, we introduce the research method and present the empirical findings. We follow this with a discussion and conclude by acknowledging some limitations of the study and suggesting potential avenues for further research. 


\section{Cultural aspects of business networking}

Business networks have been defined as "self-organizing systems" (Ritter et al., 2004), and, from a broader perspective, markets are seen as networks of businesses in which individual business units form nodes. The relationships between these nodes act as connecting threads, forming a business network (Håkansson and Ford, 2002; Håkansson et al., 2009). A business network is "two or more organizations involved in long-term relationships" (Thorelli, 1986, 37), characterized by interlinked relationships between one's suppliers and other key actors (Anderson et al., 1994). Business networking, then, is defined as the formation of these interfirm relationships (Anderson et al., 1994; Håkansson and Johanson, 2002; Lee et al., 2012), i.e., the process through which a business network manifests and develops.

These definitions largely rely on the network and its organization as the unit of analysis (Henneberg et al., 2010), but they frequently omit the fact that individual managers whose firms operate within business networks may make sense of the concept differently, depending on their cultural backgrounds. Furthermore, culture, more than the performance of the business partner, may be the underlying context of the business relationship in creating business partners' perceptions (Ellis, 2006).

The few existing cross-cultural studies on business networks mostly either consider culture as a supplementary component that does not need special emphasis (Holden, 2004), or apply cultural models such as those developed by Hofstede (1980) and Trompenaars (1993) (e.g., Cannon et al., 2010; Möller and Svahn, 2004; Voldnes et al., 2012; Williams et al., 1998). As a result, extant literature tends to apply a functionalistic perspective on culture by focusing on predefined cultural dimensions to understand research findings. This distinction constitutes a weakness when trying to uncover new cultural meanings and theories (Ellis et al., 2006; Fletcher and Fang, 2006). As Ellis et al. (2006), citing Langhoff (1997, p. 146), note:

"The significance of culture on human life cannot be explained and understood by reducing cultural studies to [Hofstede's] variables. Common to all cultures, however, is the assignment of meaning ... Human beings use and need culture to organize a coherent meaning of the world around themselves."

Focusing on cultural meanings requires an interpretative perspective on culture in which, contrary to the functionalistic stream, it is not the meaning systems that use people, but it is people employing "interpretation repertoires" to make sense of encountered situations and interactions (Ivanova-Gongne, 2015). Sensemaking (Weick, 1995; Weick et al., 2005) can be understood as "the way people make bets on 'what is going on' and what to do next" (Colville \& Pye, 2010, p. 373). Through the means of sensemaking an individual attributes meaning to events and related phenomena (see Weick, 1995; Weick et al., 2005). It is a cognitive, narrative, and communicative process, as well as an outcome of that process in the form of cognitive 
representations (Brown, Stacey \& Nandhakumar, 2008; Henneberg et al., 2010; Mattsson et al., 2015).

Business-network literature particularly highlights the importance of networks' cognitive representations through the concept of "network theory" (Mattsson, 2002) and "network pictures" (Henneberg et al., 2010; Abrahamsen et al., 2016). While this stream of literature focuses mostly on the managerial understanding of network structure and characteristics (Mattsson et al., 2015), we will examine cognitive representations of the understanding of networking and the network concept as such. The study particularly looks at how individuals attempt to assign meaning to the activity of networking, as well as the concept of networks drawing on their cultural knowledge, which relates to the process of sensemaking (see Mattsson et al., 2015).

When considering sensemaking from a cultural perspective, research focusing on cultural sensemaking (e.g., Bird \& Osland, 2006; Ivanova \& Torkkeli, 2013; Fellows \& Liu, 2016) has been sparse due to the predominant functionalistic nature of cultural studies in international business and marketing (Leung \& Morris, 2015). In turn, studies focusing solely on sensemaking among managers in a business-network context frequently take the cultural component of sensemaking for granted (Fellows \& Liu, 2016). Culture is, however, a crucial component of sensemaking, as individuals apply certain cultural frames or schemas when making sense of interactions and certain phenomena (Ivanova-Gongne, 2015).

Thus, culture in this study is regarded as a network of flexible knowledge incorporated into an individual mindset (e.g., Berry, 1999). An individual's cultural repertoire may consist not only of knowledge about national cultures, but also about traditional, professional, organizational, and other types of cultures (Ivanova-Gongne, 2015). By interacting with certain cultural groups and being involved in various cultural contexts, the individual manager broadens his or her cultural repertoire and can further use obtained knowledge when making sense of and acting in certain situations (ibid.). Thus, through the course of interacting with business partners, individuals may incorporate partners' cultural understandings into their own repertoires or create shared cultural understandings (see Ivanova-Gongne, 2015). Such understandings resemble, to some extent, the notion of inter-cognitive representations (Mouzas \& Henneberg, 2016).

To delimit our scope to one that is manageable in a single study, we use ethnicity -- i.e., the individual's origin, rather than his or her place of residence -- and business culture as our main guiding cultural concepts for interpreting obtained managerial sensemaking. Business culture entails the ways and norms of doing business in a particular country (Weck and Ivanova, 2013), whereas the ethnicity of an individual embodies the traditional cultural norms and habits that contribute to the worldview of the manager as an individual. 


\section{General characteristics of Russian and Finnish business culture}

The Russian-Finnish context provides a fitting empirical context in which to conceptualize business networking cross-culturally. The influence of history on business relationships is particularly strong in Eastern Europe (Salmi, 2000), and personal networks are predominant in Russia, where they are products of cultural heritage (Michailova and Worm, 2003 Jansson et al., 2007; Ledeneva, 1998; Mattsson and Salmi, 2013). Conversely, in Finland, business relationships are more formal and business-like, emphasizing the organizational dimension of (e.g., Konsti-Laakso et al., 2012) and strategizing in (Laari-Salmela et al., 2015) networks.

Doing business in Russia is still characterized by relatively high levels of conflict in business relationships (Radaev, 2013), whereas Finnish business culture is highly consensus-oriented (Lämsä, 2010). Radaev (2013) also found that in the Russian context, major conflicts in business relationships tend to originate from frequent contract infringements, rather than from new contract requirements as such. This suggests that in Russian business relationships, contract execution is more important than the absolute contract terms. Combined with the fact that traditional culture is still particularly important in Russian business behavior (Puffer and McCarthy, 2011), this also brings unique (Michailova and Worm, 2003) and dynamic (Hallén and Johanson, 2004) aspects into business interactions and relationships in the Russian context.

One aspect that may hinder business networking in Russia is the relatively low level of initial trust toward outsiders (Mattson and Salmi, 2013). However, Finland is a highly trusting society (Korhonen and Seppälä, 2005; Newton, 2001), reflected in its business culture. Related to the high level of trust is the fact that Finns appreciate honesty and credibility in business (Koiranen, 2002), which may cause certain problems when operating in the Russian market: For instance, Russian managers are still characterized as being opportunistic and may seek the best business opportunities in the short term, instead of trying to preserve a long-term business relationship (Jumpponen et al., 2008; Weck and Ivanova, 2013). Finally, while Western European business practice is more network-relationship-oriented (Jansson et al., 2007), Russia is still characterized by the predominance of dyadic business relationships (Kouchtch and Afanasiev, 2004). Table 1 below provides a summary of the cultural differences between Finland and Russia, as described above. 
Table 1. Basic business culture differences between Russia and Finland.

\begin{tabular}{|l|l|}
\hline Russian business culture & Finnish business culture \\
\hline Predominance of personal networks & $\begin{array}{l}\text { Predominance of formal business } \\
\text { relationships }\end{array}$ \\
\hline High levels of conflict & Looking for consensus \\
\hline Low level of trust towards outsiders & High level of trust towards outsiders \\
\hline Opportunistic behavior & Reputation-centered behavior \\
\hline Dynamic, short-term & Long-term strategy \\
\hline $\begin{array}{l}\text { Importance of traditional culture in } \\
\text { business }\end{array}$ & $\begin{array}{l}\text { Traditional culture is less important in } \\
\text { business }\end{array}$ \\
\hline Dyadic relationship orientation & Network relationship orientation \\
\hline
\end{tabular}

\section{Methodology and Data Collection}

Given the explorative aim to help illustrate the ways in which managers' cultural perspectives affect their understanding of business networking, we decided that a qualitative research approach was the appropriate method to use. Yin (2009) notes that qualitative methods are particularly suitable for obtaining in-depth knowledge on issues in focus. Qualitative methods are useful especially for researching complex business phenomena in their contexts (Eriksson \& Kovalainen, 2008), to which this study aims to contribute. Furthermore, qualitative research can be regarded as "language mastering," in which the ultimate aim is to understand "How do people construct their version of things?" (Silvermann, 2011), thereby making it appropriate for studying managerial sensemaking in business networking. Interviewing managers from different cultural backgrounds also opens up the possibility of interpreting different, culturally embedded ways in which they come to define their view of business networking on the individual level.

While few studies have focused on business networking in Russia (e.g., Aidis et al., 2008; Jansson et al., 2007; Michailova and Worm, 2003), this phenomenon has been barely examined in a Finnish or a Finnish-Russian context (e.g., Heikkilä, 2011). Thus, to highlight the phenomenon further, we are investigating a set of Finnish-Russian business dyads from the point of view of individual managers. We have conducted a series of in-depth, semi-structured interviews with six managers in three Finnish and three Russian SMEs, for a total of three business dyads (see Table 2 for more information). Each interview lasted between one and 2.5 
hours. The names of firms and respondents have been altered to preserve confidentiality.

We selected firms based on the level of their engagement in industrial marketing, which mainly concerns buyer-supplier relationships. The mechanical-engineering industry was chosen because companies in this industry tend to have narrow specializations and thereby must engage in business networking due to a lack of resources and skills for production and business operations. We also deemed this an appropriate context because it represents a setting in which business networks and networking have long been studied, and their importance to firms is heightened (e.g., Thorelli, 1986).

We selected the Finnish firms from a public database based on their level of experience in the Russian market and the presence of relationships with Russian firms. Three of the contacted firms based in Southern Finland agreed to participate in the study. The subsequent three interviews with the Russian partner managers, all from the St. Petersburg area, were conducted in Russian. By accessing the Russian firms through mentioning that we have been in contact with their Finnish partners, we were able to gain higher initial trust from respondents, thereby enhancing the interviews' credibility in terms of mutual rapport between respondents and researchers (see Ivanova-Gongne et al., 2017).

Each interviewed business dyad will be referred to henceforth as a "case," each with a specific social setting and related experiences (Crouch and McKenzie, 2006). Crouch and McKenzie (2006, p. 493) note that even "one 'case' can lead to new insights...if it is recognized that any such case is an instance of social reality" (cf. also Siggelkow, 2007). Conducting interviews from both sides of a dyad and not with respondents from non-matched companies was crucial to eliminate the role of other possible contextual factors, such as different industries, in respondents' sensemaking. It also ensured that respondents from both sides were describing the same empirical phenomena (i.e., a given business-relationship dyad), allowing us to obtain a two-sided view of all examined Russian-Finnish business relationships. Furthermore, considering dyads with a fair history of mutual interaction would allow us to see whether they had developed some shared cultural understandings through networking. In conducting the interviews, we noticed that similar themes and views arose from each of the respective Finnish and Russian managers. Therefore, we regarded the number of firms and interviews as fitting for the purposes of the study. 
Table 2. The characteristics of the case firms and the respondent managers.

\begin{tabular}{|c|c|c|c|c|c|c|c|c|c|c|}
\hline $\begin{array}{c}\text { Dya } \\
\text { d }\end{array}$ & $\begin{array}{c}\text { Fir } \\
\text { m }\end{array}$ & $\begin{array}{l}\text { Firm's } \\
\text { origin }\end{array}$ & Industry & $\begin{array}{c}\text { Specialisatio } \\
\mathbf{n}\end{array}$ & Founded & $\begin{array}{l}\text { Employee } \\
\text { S }\end{array}$ & $\begin{array}{l}\text { Experience of } \\
\text { Finnish- } \\
\text { Russian } \\
\text { relationships }\end{array}$ & $\begin{array}{c}\text { Name } \\
\text { of the } \\
\text { manage } \\
\mathbf{r}\end{array}$ & $\begin{array}{l}\text { Respondent } \\
\text { 's position }\end{array}$ & $\begin{array}{l}\text { Respondent } \\
\text { 's origin }\end{array}$ \\
\hline \multirow[b]{2}{*}{1} & A & Finnish & $\begin{array}{c}\text { Mechanica } \\
\mathrm{l} \\
\text { engineerin } \\
\mathrm{g}\end{array}$ & $\begin{array}{c}\text { Manufacturer } \\
\text { of } \\
\text { customized } \\
\text { industrial } \\
\text { filters and } \\
\text { ventilation } \\
\text { applications }\end{array}$ & 1995 & 12 & $\begin{array}{c}\text { High (started in } \\
2004-2005)\end{array}$ & Joonas & $\begin{array}{l}\text { Founder / } \\
\text { Managing } \\
\text { director }\end{array}$ & Finnish \\
\hline & B & $\begin{array}{c}\text { Russia } \\
\mathrm{n} \\
\text { (with } \\
\text { Swedis } \\
\mathrm{h} \\
\text { roots) }\end{array}$ & $\begin{array}{l}\text { Mechanica } \\
1 \\
\text { engineerin } \\
\mathrm{g}\end{array}$ & $\begin{array}{c}\text { Manufacturer } \\
\text { and } \\
\text { distributor of } \\
\text { solutions in } \\
\text { the field of } \\
\text { ventilation, } \\
\text { air cleaning, } \\
\text { welding and } \\
\text { cutting } \\
\text { Distribution } \\
\text { (for A) since } \\
2010\end{array}$ & 1989 & 700 & $\begin{array}{c}\text { High (first } \\
\text { invited/contact } \\
\text { ed A at the } \\
\text { beginning of } \\
2000 \\
\text { (first company } \\
\text { in Fin. for them) }\end{array}$ & Leonid & $\begin{array}{l}\text { Technical } \\
\text { director }\end{array}$ & Russian \\
\hline \multirow[t]{2}{*}{2} & $\mathrm{C}$ & Finnish & $\begin{array}{c}\text { Mechanica } \\
\mathrm{l} \\
\text { engineerin } \\
\mathrm{g}\end{array}$ & $\begin{array}{l}\text { Manufacturer } \\
\text { of machinery } \\
\text { for timber } \\
\text { house } \\
\text { construction }\end{array}$ & 1974 & 20 & $\begin{array}{l}\text { High (two } \\
\text { partnerships, } \\
\text { the most } \\
\text { important one } \\
\text { since 2006, } \\
\text { involved in } \\
\text { Russian } \\
\text { business since } \\
\text { ca.1999) }\end{array}$ & Seppo & $\begin{array}{l}\text { Owner / } \\
\text { Managing } \\
\text { director }\end{array}$ & Finnish \\
\hline & $\mathrm{D}$ & $\begin{array}{c}\text { Russia } \\
\mathrm{n}\end{array}$ & $\begin{array}{c}\text { Mechanica } \\
\text { l } \\
\text { engineerin } \\
\mathrm{g}\end{array}$ & $\begin{array}{l}\text { Distributor of } \\
\text { ready-made } \\
\text { mechanical- } \\
\text { engineering } \\
\text { products }\end{array}$ & $\begin{array}{c}1995 / 199 \\
6\end{array}$ & 20 & $\begin{array}{c}\text { High } \\
\text { Relationships } \\
\text { with C since } \\
2002 \text { (first } \\
\text { contact), started } \\
\text { working since } \\
2004 / 2005\end{array}$ & Petr & $\begin{array}{l}\text { Owner \& } \\
\text { Founder / } \\
\quad \text { CEO }\end{array}$ & Russian \\
\hline \multirow[t]{2}{*}{3} & $\mathrm{E}$ & Finnish & $\begin{array}{c}\text { Mechanica } \\
\mathrm{l} \\
\text { engineerin } \\
\mathrm{g}\end{array}$ & $\begin{array}{c}\text { Design, } \\
\text { manufacturin } \\
\text { g and sales of } \\
\text { automation } \\
\text { mechanisms } \\
\text { in industrial } \\
\text { doors and } \\
\text { gates }\end{array}$ & 1953 & 58 & $\begin{array}{l}\text { Moderate } \\
\text { (started in } \\
\text { 2008, at the } \\
\text { early stages) }\end{array}$ & Mikko & CEO & Finnish \\
\hline & $\mathrm{F}$ & $\begin{array}{c}\text { Russia } \\
\mathrm{n}\end{array}$ & $\begin{array}{c}\text { Mechanica } \\
\mathrm{l} \\
\text { engineerin } \\
\mathrm{g}\end{array}$ & $\begin{array}{c}\text { Manufacturer } \\
\text { of automatic } \\
\text { gates }\end{array}$ & 2001 & 50 & $\begin{array}{l}\text { Moderate (5-6 } \\
\text { years, started in } \\
2006-2007)\end{array}$ & Pavel & $\begin{array}{l}\text { Owner \& } \\
\text { Founder / } \\
\text { CEO }\end{array}$ & Russian \\
\hline
\end{tabular}


We first asked the managers to describe how they understood "business network" and "business networking" in both Finnish and Russian contexts. These questions are what Spradley (1979) refers to as "native-language questions," which are asked to understand "the terms and phrases most commonly used in the cultural scene" (p. 51) in relation to the term mentioned in the question. Thus, the aim was to understand their native language in terms of the studied concepts. Second, to capture both the organizational and individual levels of networking, we applied a set of questions based on the works of Ritter (1999) and Ritter, Wilkinson, and Johnston (2002), which have distinguished between the two levels conceptually (for a listing of the specific questions, see Appendix 1). The related questions were open-ended, and the interviews were conducted in the form of conversations, rather than by strictly following any interview protocols. Fisher (1993), as well as King and Bruner (2000), note that indirect questioning offers one way to overcome social- desirability bias in self-reported data. Thus, to avoid self-reporting bias, and to obtain the manager's sensemaking on the nature of individual networking, we not only asked the interviewees about their personal views on networking, but also on networking from the partner's point of view, e.g., "Based on your experience with your Russian partner, how would you characterize their ability to deal with you?" This approach is based on the fact that individuals apply their own cultural preconceptions when making sense of a certain event or phenomenon (cf. Ivanova-Gongne, 2015).

The respondents' interpretations resulted in several narratives. Narratives in this study are regarded as the "linguistic expression of sensemaking" and "form the basic 'data mass' from which it is possible to extract and interpret what has taken place and why" (Ivanova-Gongne \& Törnroos, 2017, p. 105). We view narratives through an interpretative approach by focusing on understanding the individual reasoning behind storied accounts of the events and certain phenomena (Ivanova-Gongne \& Törnroos, 2017). We further applied a categorical-content approach in line with Lieblich et al. (1998). While the categorical approach relates to extracting certain sections or words related to the studied phenomena, the content approach looks for meaning in the narratives and/or certain sections and words (ibid.). The analysis of individual narratives consisted of the following steps. First, we examined the whole narrative to discern general sense and meaning. Next, we did a second reading of the narrative to elicit particular cues that respondents put forward in explaining their understanding of the phenomena in focus. We particularly looked for contrasting perspectives from respondents in each dyadic case. After this procedure, we examined the specific sections and words from the individual narratives, from which we extracted those that were imbued with cultural meaning and offered the best representation of the phenomena from the respondents' perspectives.

The credibility of the interpretation of respondents' narratives was further ensured through prolonged engagement by researchers in learning about the culture (Lincoln and Guba, 1985). In the case of this study, prolonged engagement was achieved, given that the researchers are native members of the cultures examined, i.e., of Finnish and Russian origin. Therefore, they have extensive personal knowledge of their respective traditional cultures, which makes deciphering 
culturally specific references in the interviews more credible. The interviews began with the managers describing their personal histories and daily work. In analyzing the interviews, we then viewed interviewees' responses juxtaposed with their professional and personal histories. Finally, given that each respondent's story is situation-specific, we did not strive for wide generalizability in the results. However, we aimed to provide an accurate description and interpretation of the findings, allowing for their potential transferability to other contexts (ibid.).

\section{Perceptions of Organizational and Individual Business Networking}

\subsection{Organizational networking}

A clear distinction emerged between Finnish and Russian managers' sensemaking narratives when they were asked about their understanding of business networking. The Finnish respondents had an implicit conception of business networks that closely resembles prevalent academic definitions, repeatedly referring to business networking as a form of long-term strategic planning at the organizational level, manifested through the lens of organizational longterm goals and customer orientation. The need for networking was particularly justified by lack of owned resources, which also corresponds with business marketing literature (Håkansson et al., 2009):

"[Business networking occurs]...for the customer's benefit and is essential for the company's success." --Joonas, managing director of A, Dyad 1

"I think that it's very common nowadays and has even become a necessity. Our company puts great emphasis on business networking, as we have so many suppliers and no production of our own, meaning that networking is really essential for us." --Seppo, owner/managing director of C, Dyad 2

"Networking is always vital, and it is the job of the salespeople to create and manage this type of network." ---Mikko, CEO of E, Dyad 3

The managers with a Russian cultural background, in contrast, seemed to have no conception of inter-organizational business networks, despite the concept having been clarified by researchers. On the contrary, Russian managers all questioned the entire concept and found it challenging to make any sense of the term:

"I don't quite understand what inter-firm networks are." --Leonid, technical director at B, Dyad 1 
"Inter-company network? ... Network companies? Am I right?" --Petr, owner and founder/CEO of D, Dyad 2

"I did not understand what you meant by that..." --Pavel, owner and founder/CEO of F, Dyad 3

The above responses present a clear contradiction between the managers in their understanding of organizational, long-term, strategic perspectives concerning the benefits of operating in larger sets of business relationships. These differences might mirror the notions of the distinct nature of Russian business culture in general. In business collaborations and interactions, in particular, studies have found that dyadic types of relationships still appear to prevail in Russia (Jansson et al., 2007; Kouchtch and Afanasiev, 2004). Therefore, what emerged as a concept of business networks for managers with Russian cultural backgrounds was notably different from the Finnish context:

Well, in Russia, I don't think it (the business network as a concept) exists. This (phenomenon) only occurs in big companies; it's the corporate network." - Leonid, technical director at B, Dyad 1

"I'm not sure what to call it...Like I understand, we are usually a supplier, and there is the customer, but the customer we do the work for is not always the end customer (with whom we interact). It may be the subcontractor or the main contractor who is the final customer." --Pavel, owner and founder/CEO of $F$, Dyad 3

"The word 'network' basically means that, when you have thousands of similar firms (distributors) in one city or in one region that sell or do something, but there is one owner...that owns the bulk of the enterprises." --Petr, owner and founder/CEO of D, Dyad 2

We interpret the differences in these responses as reflecting the fact that in the Russian language, there are several connotations of the word network in a business context. First, it equates to the word chain, which may be why Pavel saw the network as a supply chain. Another meaning of the term relates to a "multi-level marketing company," i.e., an owner company with a large number of subsidiaries or distributors in multiple regions, which is how Petr and Leonid interpreted the term.

The responses also reflect a difference in long-term strategic thinking among the managers. For example, in contrast to the Russian managers, the Finnish manager Joonas clearly understood business networking as a long-term, customer-oriented phenomenon. As Shinkle et al. (2013) point out, long-term strategic thinking is more effective when the institutional environment is also conducive to market-oriented thinking, and this tends to be more prevalent in developed markets. Managers embedded in the Russian business culture may view the market largely through competitive lenses (cf. de Vries et al., 2004), rather than through collaborative ones. 
In sum, when we analyzed and compared the sensemaking of the Finnish and Russian managers with the help of a categorical-content approach to narratives (see section 3 ), we found that the former possessed a clear picture of business networking as a process that seeks increased adherence to customer orientation and other long-term strategic objectives on the company level. This image corresponds with the traditional academic view of business networking, a unit of analysis tending to be on the organizational, rather than the individual, level, i.e., within the interaction framework (Håkansson, 1982; Håkansson and Snehota, 1989). However, on the basis of the empirical results, we argue that a manager from a different cultural background may have different ways of sensemaking that do not correspond with the prevalent views on business networking. In this case, the managers with a Russian background did not have a ready-made picture in their minds of what business networking entailed, but rather perceived it as a supply chain or a multi-level marketing organization.

\subsection{Individual networking}

Compared with the organizational side of business networking, individual managers' reactions to questions about the individual side of networking were almost completely in opposition to each other. In general, the Finnish managers eschewed assessing business networking from an individual-level point of view. For instance, when asked to characterize how their partners were able to sense and react to possible inter-personal conflicts in the relationship, they referred to their partners in a plural sense, implying an organizational, rather than an individual, level:

"Hard to say. Perhaps they have learnt by now (how to proactively sense and react to possible conflicts]; I'm not sure, though." --Seppo, owner/managing director of C, Dyad 2

"I haven't really been thinking about that, but they have never been arrogant or pushy. I can't say that we have felt any pressure from their side, and we've always been able to discuss things." --Joonas, managing director of A, Dyad 1

These quotes reflect confusion and dissonance in the sensemaking of the Finnish managers when being asked to characterize the individual side of networking. Although they had an understanding of business networking as a phenomenon on the organizational and strategic level in their sensemaking on interactions, the Finnish managers did not accentuate the importance of personal relationships with their Russian business partners, as they did not acknowledge the individual side at all:

"We communicate directly with the customers, but we have a couple of representatives out there who we also interact with. They also interact directly with the customer, but I'm not sure if you can call that networking." --Seppo, owner/managing director of C, Dyad 2

The Finnish managers did admit, however, that their cultural background and the business 
culture of their companies had played a role in their perceptions of the importance of the individual side of business networking. As one manager noted:

"The communication between Finnish companies is quite poor, and the emphasis in the communication is on the issue itself. We do things quite straightforwardly, and this type of rigidity lacks the psychological aspect." --Mikko, CEO of E, Dyad 3

In contrast, the Russian managers, who did not seem to grasp the suggested conception of business networks, instead intuitively understood the individual, social dimension of business networking:

"We know what's going on (on the market), even without communicating with the plant. If people go to another business, then we know exactly what's going on there (in their new business). So, we have no problems with this (getting information about the market). The information is so rich, well, and then Russian people love to talk...So, everybody knows everything. This information often atrophies of course, like gossip usually does, but you can read between the lines and get the necessary information." --Petr, owner and founder/CEO of D, Dyad 2

Petr's understanding of the issue reflects the Russian cultural practice of obtaining information, particularly through gossip, which is very socially oriented. Gossip was and still is highly trustworthy in the context of Russian social relationships, and it is frequently considered an authoritative source of information (Osetrova, 2011).

Well, I don't always understand why he (the Finnish partner) has some problems (difficulties). From the point of view...well, maybe it's the business ethics in the West, like why do you need to tell your partner about your difficulties...or anticipate some events..." --Leonid, technical director at B, Dyad 1

Leonid's sensemaking points to the importance of having more open communications with, and informal, tacit knowledge about, one's partners. Unlike Western European companies, which tend to value commercial exchange and explicit knowledge, social exchange still is an essential practice in Russia, during which interpersonal and tacit knowledge is shared among counterparts (Casanueva et al., 2013). One Russian manager noted this:

"You know, it's simply not common for these gentlemen [Finnish managers] to put themselves in the position of somebody else. Zero ability. They just ... we are the ones who constantly put ourselves in someone else's position, sometimes we stand in this position for a long time. But it isn't common for them (Finnish managers) to do so. They have some kind of ethic, they follow it, and believe it's enough. They don't put themselves in anyone else's position; they cannot even imagine themselves in someone else's position. It's because they have this kind of mentality, actually." - Petr, owner and founder/CEO of D, Dyad 2 
Petr bases his interpretation of the problem on traditional Russian culture. His discourse about Russians putting themselves in someone else's position relates to the concept of "giving yourself," "giving a part of your 'dusha", or "putting 'dusha' into it." The concept of "dusha" is essential in Russian social relations and stresses the importance of emotions, whereas "giving a part of your 'dusha"' and "putting 'dusha' into it" imply dedicating a high level of personal time and effort to help someone (Pesmen, 2000). Furthermore, an "open dusha" and "razgovor po dusham" are considered crucial elements in interpersonal relations, implying unconstrained and open interaction (Wierzbicka, 2002). This corresponds with the previous citation from the interview with Leonid.

We interpret these responses as illustrating the fact that in the Russian context, business relationships can function through individuals, rather than through organizations, a notion in line with Jansson et al. (2007). As Buckley et al. (2005) note, the effective transfer of knowledge between business partners requires simultaneous transfer of technical and social knowledge. We found that, whereas the Russian managers seemed to use individual relationships for the efficient transfer of both types of knowledge, their Finnish counterparts tended to emphasize the technical side. We suggest that this phenomenon elicits less-effective knowledge transfer between both cultures.

Therefore, it is possible that the underlying factor behind the differences in managerial understanding of business networking is the effectiveness of transferring knowledge in business relationships. The Finnish managers seemed to perceive the exchange through formal customer relationships, whereas their Russian counterparts relied more on personal relationships. This implies that the organizational side of business networking seems to dominate in the Finland context, whereas the personal side, through the people involved in the business relationship, appears to be more heavily emphasized in the Russian context (see Table 3). 
Table 3. Summary of the results.

\begin{tabular}{|c|c|c|}
\hline & Russian managers & Finnish managers \\
\hline $\begin{array}{l}\text { Understanding of } \\
\text { organizational } \\
\text { business } \\
\text { networking }\end{array}$ & $\begin{array}{l}\text { - Not part of inter-firm business } \\
\text { networking } \\
\text { - Misconception with supply chain, } \\
\text { corporate network (MNCs), } \\
\text { distribution network } \\
\text { - Market as a competition platform } \\
\text { view }\end{array}$ & $\begin{array}{l}\text { - Long-term strategic action } \\
\text { - High customer orientation } \\
\text { - Organizational long-term goals } \\
\text { - Lack of own resources as the main motive } \\
\text { for networking }\end{array}$ \\
\hline $\begin{array}{l}\text { Understanding of } \\
\text { personal business } \\
\text { networking }\end{array}$ & $\begin{array}{l}\text { Individual relationships: } \\
\text { - Obtaining information on } \\
\text { partners/for networking through } \\
\text { social "gossip" } \\
\text { - Open interpersonal communication } \\
\text { with informal, tacit knowledge on the } \\
\text { partner } \\
\text { - Social exchange } \\
\text { - Individuals as a way station for } \\
\text { transfer of both technical and social } \\
\text { knowledge }\end{array}$ & $\begin{array}{l}\text { Not part of inter-firm business networking: } \\
\text { - Regarding the partner as an organization } \\
\text { ("we") } \\
\text { - Lack of interpersonal aspect as part of } \\
\text { Finnish business culture and } \\
\text { communication } \\
\text { - Commercial exchange and explicit } \\
\text { knowledge } \\
\text { - Individuals as a way station for transfer of } \\
\text { technical knowledge }\end{array}$ \\
\hline $\begin{array}{l}\text { Culture determining } \\
\text { the level of business } \\
\text { networking }\end{array}$ & $\begin{array}{l}\text { Traditional culture: } \\
\text { - Concept of "dusha" as an essential } \\
\text { component in social relations } \\
\text { - Traditions of "gossip" }\end{array}$ & $\begin{array}{l}\text { Business culture: } \\
\text { - Detachment of business from private life } \\
\text { - Importance of customer orientation and } \\
\text { long-term goals }\end{array}$ \\
\hline
\end{tabular}

\section{Discussion}

The results suggest that the cultural backgrounds of individual managers and the business cultures from which their firms originate can make a substantial contribution to their understanding of what business networking entails, and that this may further influence their business behavior. The Finnish managers we interviewed all conceptualized business networking as part of their long-term organizational strategy and repeatedly perceived their customers and other business partners as organizations rather than individuals. However, their Russian counterparts had a contrary view; they emphasized the process of engagement in personal relationships and personalized their business partners on an individual level. Thus, personal relationships are still "deeply ingrained into the Russian psyche" (Butler and Purchase, 2008, p. 538). This may indicate the different character of business networking in the respective countries and confirm the notion of previous literature (e.g., Jansson et al., 2007), i.e., that Russia is still a developing market that largely differs from the West. 
Butler and Purchase (2008), based on their 2004 study, assume that with less exposure to the social system, the importance of personal relationships among the new generation of managers may diminish. Our study, however, suggests that presently, over a decade since that study, the situation remains as is, most likely due to the older generation's key role in Russian business networking and relationships across cultures. Although the managers interviewed in our study were in their late 40s-50s and from the older generation of management, we argue that the preference toward personal relationships may endure, as Russian managers' mindset is deeply rooted in traditional cultural beliefs, which are slow to change. While having a more Westernoriented education, the younger generation of managers is still heavily influenced by traditional cultural beliefs, which are passed on to them by the older generation. This phenomenon, however, requires further research by reflecting on the sensemaking of business networking, which emanates from the younger generation of managers. Additionally, although the Russians interviewed were from the St. Petersburg area, where people are more Western-oriented (Ralston et al., 2008), this evidently did not play a role in managerial sensemaking of business networking, based on the results.

We also surmise that even though the dyads investigated have been interacting with each other for a considerable amount of time, they have not yet reached a common cultural understanding of networking. This also may indicate the persistence of traditional and ethnic culture in managerial sensemaking for certain phenomena. Thus, for example, in a Russian context, the traditional cultural concept of 'dusha' still plays an important role in business culture and businessnetworking practices. However, despite their contrary understanding of the level at which business networking as a phenomenon occurs, both Finnish and Russian managers agreed that the ability to foster and manage business relationships is essential, thereby confirming the notion that "no business is an island" (Håkansson and Snehota, 1989; Håkansson and Snehota, 2006). Consequently, considering the results from the Russian side of the dyads, we postulate that in the context of the current Russian business culture, a more accurate phrase might be "no manager is an island."

The findings also seem to imply that, in addition to the accentuated importance of individual business networking in the country, Russia may be less market- and long-term-oriented than certain more-developed market environments such as Finland, and may be less strongly attached to the level of organizational strategy. In this, our results echo the findings of Danis et al. (2010), indicating that successful networking by managers is essential to achieving continued growth at a firm, regardless of its business relationships. It is particularly essential in environments undergoing recent or ongoing institutional transition, and for firms embedded in cross-cultural business relationships spanning emerging and developed markets. Therefore, whereas we would expect managers from some developed countries such as Finland to concentrate on the organizational side of business networking, their Russian counterparts may tend to concentrate on the personal level (see figure 1 for the resulting conceptual model). These different understandings could lead to unnecessary conflicts in the development of business relationships. 
The notion that the cultural background of a manager may prevent him or her from understanding central networking concepts may arise from the fact that the concept of business network that is prevalent in industrial marketing research is based on the definitions and conceptualizations of Western academics. Furthermore, these aspects mostly rely on data from U.S. and Western European firms (see Ellis et al., 2006). Thus, we argue that the term may suffer from ethnocentricity, which is evident in the different interpretations and underlying process, depending on whether or not the cultural background of the manager and the originating business culture of his firm correspond to established definitions. We would rather point to the variety of meanings that the term may have in different cultures, and note that the results of this study indicate a need to adapt the concept of a (business) network to the Russian cultural-linguistic context, instead of simply translating it verbatim.

Overall, the results suggest a set of distinct differences between managers originating from two cultures, in that the cultural backgrounds of the managers determine the level of networking most relevant to business networking (see figure 1). Whereas the Finnish managers may perceive the practice as an organizational strategy, their Russian counterparts may bring it down to the level of the individual. The study finds this difference in a dyadic context, in which we can illustrate the differences in networking from the perspectives of both sides of the dyad.

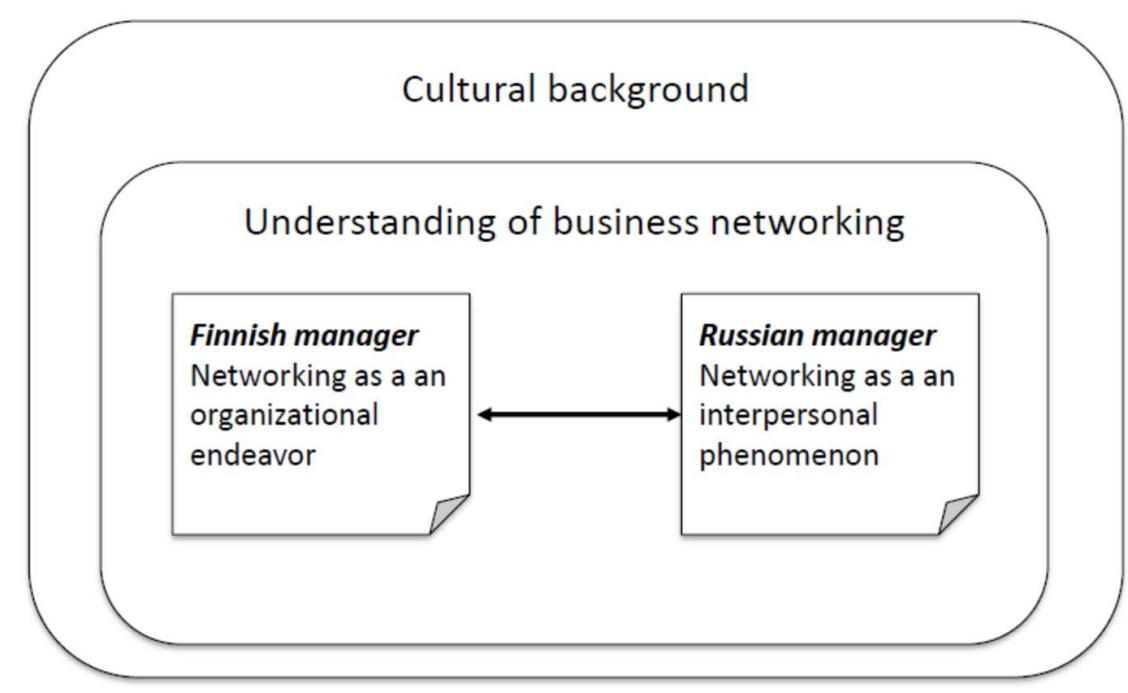

Figure 1. The conceptual model.

\section{Conclusion}

Our aim in this study was to explore how managers from different cultural backgrounds make sense of business networking. Several implications emerged from the empirical part, which consisted of a series of interviews with Finnish and Russian managers involved in mutual 
business relationships. We further conducted an analysis of the resulting narratives.

The study contributes both to theory and methodology, while also providing a basis to postulate on managerial implications for firms and managers involved in cross-cultural business relationships. Theoretically, the study adds to the scant knowledge on the ways in which individual managers' cultures and cultural backgrounds affect their sensemaking and business networking, particularly by applying a cross-cultural approach based on individual sensemaking of managers from distinct cultural backgrounds. Methodologically, this is one of very few studies to illustrate differences through individual sensemaking on both sides of the relationship dyad and to do so accounting for both developed and emerging-market environments.

\subsection{Theoretical and methodological contributions}

The specific theoretical contributions of the study are the following. First, by highlighting the differences in managerial sensemaking on business networks and networking, the study contributes to literature on industrial marketing and networks by problematizing some of the concepts prevalent in the field, in the manner suggested by Alvesson and Sandberg (2011). Namely, the results of this study suggest that the distinct nature of business networking in some cultural contexts (e.g., Michailova and Worm, 2003) may not only influence networking practices, but also may impact the very understanding through which managers make sense of business networks and networking.

Second, our study contributes to the literature by attesting to the importance of understanding and accounting for both organizational and individual levels of business networking when operating internationally. These business-networking levels may be of varying importance depending on the level of market development. Like Russia, personal networking is of high importance in other emerging business contexts, e.g., China (Michailova and Worm, 2003), African nations (Ibeh et al., 2012), and Brazil (Carrillo Rivera, 2007). Future research could use these findings to extrapolate further and highlight culturally similar and distinct sensemaking phenomena.

Third, in line with Michailova and Worm (2003), we suggest that, given the differing business cultures, personal networks related to business should be managed accordingly in different countries. It seems that businesses and many managers in Russia still favor dyadic business relationships over networks (see also Jansson et al., 2007). In terms of conducting business across borders, this also implicitly echoes the findings by Mattsson and Salmi (2013), in that developing strong personal networks with business partners seems to characterize business networks in Russia. Thus, the present study also extends these findings by highlighting the importance of personal relationships and the nature of business networking in Russia as an almost squarely individual endeavor.

By providing an updated view, albeit one that resembles previous literature, on the importance of 
personal networks in Russia, our study indicates that although Russian business in big cities, such as St. Petersburg, may be trying to implement Western business culture and thinking, the cultural traditions developed over centuries are hard to replace. Apart from highlighting the distinctions between Russian and Western business culture and their impact on the concept of networking, the results also illustrate how a presumed Western culture such as Finland adheres quite closely to extant literature and conceptualizations. This is notable, as the Finnish business culture very rarely has been examined either individually or through comparative studies involving other cultures. As the results align with the notion of Finnish business culture adhering to extant academic literature on networks, it presents a context in which networking is mainly seen from the organizational unit of analysis. Thus, we would surmise that the managerial implications arising from extant research on networks can, with some certainty, be applied to the Finnish context, yet the Russian context provides a challenge that can be evident in business relationships encompassing both countries.

Finally, the core methodological contribution lies in highlighting managers' sensemaking from both sides of dyadic business relationships. By applying a sensemaking approach investigating both sides of business dyads, this study extends extant research on business-to-business relationships, which tends to focus on only one side of the dyad (e.g., Leek et al., 2006; Öberg, 2010; Tidström and Hagberg- Anderson, 2012). The importance of looking at dyads when studying cross-cultural issues from an individual perspective lies in discerning differences in traditional and business cultures, and diminishing the impact of other cultural backgrounds (e.g., industrial) on managerial sensemaking.

\subsection{Managerial implications}

The main managerial implication of our results lies in confirming the importance of interpersonal interactions and networking in modern Russia. Thus, managers entering the Russian market still need to account for traditional cultural aspects when doing business with Russian managers. For example, understanding the traditional cultural concept of "dusha" is crucial to comprehending Russian business culture and its networking ways. Thus, for managers with different cultural backgrounds and sensemaking ways, the results contain several implications. First, they highlight the importance of taking the time and effort to develop personal relationships when aiming to develop business networks for enterprises in Russia. Second, the results must emphasize the importance of taking the time to familiarize oneself with both the business and traditional culture to network successfully in Russia. They also indicate the need for managers to understand the possibility of different understandings of certain terms, which may reflect on their partners' actions.

Although noting limitations for generalizability from such a phenomenological study setting, we also suggest that managers may need to re-adjust their interactions with Russian managers to emphasize less on sticking to core competencies of their respective enterprises, and more on 
profit maximization and cost minimization across arising business opportunities in general. From the point of view of Russian business leaders, the results imply that they should not try to copy Western business culture (cf. May et al., 2005), but rather adapt it to local traditions and beliefs as needed to nurture business relationships.

The results also underscore the value of bi-cultural employees who can adapt to both cultural assumptions in a business dyad from the point of view of the company, e.g., in the FinnishRussian dyad, a naturalized Russian Finn may be able to bridge the two cultures and facilitate an increasingly effective intercultural business relationship. The danger of such a practice, from a managerial point of view, is the assumption that a business partner talking in similar terms possesses a similar understanding of them. This study's aforementioned findings on the term network indicated that such assumptions can be faulty. Consequently, the results call into question the conditions in which it is beneficial for a company to develop organizational capabilities related to networking (e.g., Ritter et al., 2002; Mitrega et al., 2012), as the very concept of the underlying process can have different meanings for managers, depending on their cultural backgrounds.

\subsection{Limitations and further research}

A limitation of the study is its phenomenological nature, which requires further empirical research on larger samples to claim generalizability of study results. We classified the respondents according to their cultural backgrounds, but the question of how definitive these classifications are remains to be seen because an individual's cultural background is complex and may contain several cultural layers. However, we believe that the empirical results obtained provide some clarification on how cultural background may shape the managerial understanding of concepts such as business networking. We also note that in the examined dyads, the informants were all middle-age males, which can impact their narratives on sensemaking. Therefore, future studies should seek to include business dyads in which gender and age distributions are more diverse to acquire a more comprehensive view of the individual sensemaking process across genders, generations, and industry-sector contexts.

Further research also should be conducted on the differences in managerial sensemaking of business networking in the context of other developing countries, which would allow for drawing a more holistic "Eastern" perspective on this phenomenon. Finally, although a few recent studies have considered the individual level of business relationships and networking (e.g., Ellis and Hopkinson, 2010; Leek and Mason, 2010; Tähtinen and Blois, 2011), we hope that our study will serve as an inspiration for more industrial marketing studies that use individuals as the core unit of analysis. Thus, this study provides a starting point in researching this complex phenomenon. 


\section{References}

Aidis, R., Estrin, S. and Mickiewicz, T. (2008). Institutions and entrepreneurship development in Russia: A comparative perspective. Journal of Business Venturing, Vol. 23, No. 6, pp. 656672 .

Abrahamsen, M. H., Henneberg, S. C., Huemer, L., and Naudé, P. (2016), "Network picturing: An action research study of strategizing in business networks", Industrial Marketing Management, Vol. 59, pp. 107-119.

Alvesson, M. and Sandberg, J. (2011), "Generating research questions through problematization”, Academy of Management Review, Vol. 36, No. 2, pp. 247-271.

Anderson, J.C., Håkansson, H. and Johanson, J. (1994), "Dyadic business relationships within a business network context", Journal of Marketing, Vol. 58, No. 4, pp. 1-15.

Berry J.W. (1999), "Emics and etics: A symbiotic conception", Culture \& Psychology, Vol. 5, No. 2, pp. 165-171.

Bird, A. and Osland, J.S. (2006), "Making sense of intercultural collaboration", International Studies of Management and Organization, Vol. 35, No. 4, pp. 115-132.

Bouchard, V. and Basso, O. (2011), "Exploring the links between entrepreneurial orientation and intrapreneurship in SMEs", Journal of Small Business and Enterprise Development, Vol. 18, No. 2, pp. 219-231.

Brown, A.D., Stacey, P. and Nandhakumar, J. (2008), "Making sense of sensemaking narratives", Human Relations, Vol. 61, No. 8, pp. 1035 - 1062.

Buckley, P.J., Carter, M.J., Clegg, J. and Tan, H. (2005), "Language and Social Knowledge in Foreign-Knowledge Transfer to China", International Studies of Management and Organizations, Vol. 35, No. 1, pp. 47-65.

Butler, B. and Purchase, S. (2008), "Use of social capital among Russian managers of a new generation”, Industrial Marketing Management, Vol. 37, No. 5, pp. 531-538.

Cannon, J.P., Doney, P.M., Mullen, M.R. and Petersen, K.J. (2010), "Building long- term orientation in buyer-supplier relationships: The moderating role of culture", Journal of Operations Management, Vol. 28, No. 6, pp. 506-521.

Carrillo Rivera, J.M. (2007), "An ex-post comparative analysis of SME formation in Brazil and Mexico", International Journal of Emerging Markets, Vol. 2, No. 2, pp. 144 - 165. 
Casanueva, C., Castro, I. and Galán, J. L. (2013), "Informational networks and innovation in mature industrial clusters". Journal of Business Research, Vol. 66, No. 5, pp. 603-613.

Casson, M. (Ed.). (2013). The Growth of International Business (RLE International Business). Routledge: New York.

Colville, I. and Pye, A. (2010), "A sensemaking perspective on network pictures", Industrial Marketing Management, Vol. 39, No. 3, pp. 372-380.

Coviello, N. E. and Munro, H. J. (1995), "Growing the entrepreneurial firm: networking for international market development”, European Journal of Marketing, Vol. 29, No. 7, pp. 4961 .

Crick, D. and Spence, M. (2005), "The internationalization of 'high performing' UK high-tech SMEs: A study of planned and unplanned strategies", International Business Review, Vol. 14, pp. 167-185.

Crouch, M. and McKenzie, H. (2006), "The logic of small samples in interview-based qualitative research”, Social Science Information, Vol. 45, No. 4, pp. 483-499.

Danis, W.M., Chiaburu, D.S. and Lyles, M.A. (2010), "The impact of managerial networking intensity and market-based strategies on firm growth during institutional upheaval: A study of small and medium-sized enterprises in a transition economy", Journal of International Business Studies, Vol. 41, pp. 287-307.

Davidsson, P., and Honig, B. (2003), "The role of social and human capital among nascent 'S'] entrepreneurs", Journal of Business Venturing, Vol. 18, No. 3, pp. 301-331.

de Vries, M.K., Shekshnia, S., Korotov, K. and Florent-Treacy, E. (2004), The new global Russian business leaders: Lessons from a decade of transition, European Management Journal, Vol. 22, No. 6, pp. 637-648.

Ellis, N. and Hopkinson, G. (2010), "The construction of managerial knowledge in business networks: Managers' theories about communication", Industrial Marketing Management, Vol. 39, No. 3, pp. 413-424.

Ellis, P.D. (2006), "Factors affecting the termination propensity of inter-firm relationships", European Journal of Marketing, Vol. 40, Nos. 11/12, pp. 1169-1177.

Eriksson, P. and Kovalainen, A. (2008), Qualitative methods in business research, London, UK: Sage Publications. 
Fellows, R. F. and Liu, A. M. M. (2016), "Sensemaking in the cross-cultural contexts of projects", International Journal of Project Management, Vol. 34, pp. 246-357.

Fisher, R.J. (1993), "Social Desirability Bias and the Validity of Indirect Questioning", Journal of Consumer Research, Vol. 20, No. 2, pp. 303-315.

Fletcher, R. and Fang, T. (2006), "Assessing the impact of culture on relationship creation and network formation in emerging Asian markets", European Journal of Marketing, Vol. 40, Nos. 3/4, pp. 430-446.

Gao, H., Knight, J.G. and Ballantyne, D. (2012), "Guanxi as a gateway in Chinese-Western business relationships", Journal of Business \& Industrial Marketing, Vol. 27, Iss. 6, pp. 456 467.

Hallén, L. and Johanson, M. (2004), "Integration of relationships and business network development in the Russian transition economy", International Marketing Review, Vol. 21, No. 2, pp. 158-171.

Heikkilä, K. (2011), A business network view on managing MNC relationships with state actors. Russian public officials in Finnish MNC business networks, Turku School of Economics: Sarja/ Series A-10:2011.

Henneberg, S. C., Naudé, P. and Mouzas, S. (2010), "Sense-making and management in business networks - Some observations, considerations, and a research agenda", Industrial Marketing Management, Vol. 39, No. 3, pp. 355-360.

Hill, J., and Tiu Wright, L. (2001), "A qualitative research agenda for small to medium-sized enterprises”, Marketing Intelligence \& Planning, Vol. 19, No. 6, pp. 432-443.

Holden, N. (2004), Why marketers need a new concept of culture for the global knowledge economy, International Marketing Review, Vol. 21, No. 6, pp. 563-572.

Håkansson, H. (ed.). (1982), International marketing and purchasing of industrial goods. New York:Wiley.

Håkansson, H. and Ford, D. (2002), "How should companies interact in business networks?" Journal of Business Research, Vol. 55, No. 2, pp. 133-139.

Håkansson, H., Ford, D., Gadde, L-E., Snehota, I. and Waluszewski, A. (2009), Business in networks, Wiley, New York, NY. 
Håkansson, H. and Johanson, J. (2002), "Formal and informal cooperation strategies in international industrial networks", in Contractor, F. (Ed.), Cooperative strategies and alliances in international business: Joint ventures and technology partnership between firms, Pergamon Press, Oxford, UK, pp. 369-379.

Håkansson, H. and Snehota, I. (1989), "No business is an island: the network concept of business strategy", Scandinavian Journal of Management. Vol. 5. No. 3. pp. 187-200.

Håkansson, H. and Snehota, I. (eds). (1995), Developing Relationships in Business Networks, Routledge, London. 'ispep]

Hofstede, G. (1980), Culture's Consequences: International Differences in Work-Related Values, Sage, Beverly Hills, CA.

Ibeh, K., Wilson, J. and Chizema, A. (2012), "The internationalization of African firms 19952011: Review and implications", Thunderbird International Business Review, Vol. 54, No. 4, pp. 411-427.

Ivanova, M. and Torkkeli, L. (2013), "Managerial sensemaking of interaction within business relationships: A cultural perspective", European Management Journal, Vol. 31, No. 6, pp. 717-727.

Ivanova-Gongne, M. (2015), "Culture in business relationship interaction: An individual perspective", Journal of Business \& Industrial Marketing, Vol. 30, No. 5, pp. 608-615.

Ivanova-Gongne, M., Koporcic, N.,Dziubaniuk, O. and Mandják, T. (2017) [Forthcoming], "Collecting rich qualitative data on business relationships and networks in CEE countries: Challenges and plausible solutions", Industrial Marketing Management.

Ivanova-Gongne, M. and Törnroos, J-Å. (2017), "Understanding cultural sensemaking of business interaction: A research model", Scandinavian Journal of Management, Vol. 33, No. 2, pp. 102-112.

Jansson, H., Johanson, M. and Ramström, J. (2007), "Institutions and business networks: A comparative analysis of the Chinese, Russian, and West European markets", Industrial Marketing Management, Vol. 36, pp. 955-967.

Jumpponen, J., Ikävalko, M. and Pihkala, T. (2008), "Management and change in turbulent times: How Russian Small Business Managers perceive the development of their business environment?", Journal of Business Economics and Management, Vol. 9 No. 2, pp. 115-122.

King, M. F. and Bruner, G. C. (2000), "Social desirability bias: A neglected aspect of validity 
testing", Psychology \& Marketing, Vol. 17, pp. 79-103.

Knight, G. A. and Cavusgil, S. T. (2004), "Innovation, organizational capabilities, and the bornglobal firm”, Journal of International Business Studies, Vol. 35, No. 2, pp. 124-141.

Koiranen, M. (2002), “Over 100 years of age but still entrepreneurially active in business:

Exploring the values and family characteristics of old Finnish family firms", Family Business Review, Vol. 15, pp. 175-187.

Konsti-Laakso, S., Pihkala, T., and Kraus, S. (2012), "Facilitating SME innovation capability through business networking", Creativity and Innovation Management, Vol. 21, No. 1, pp. 93-105.

Korhonen, J., and Seppälä, N. (2005), "The Strength of a High-Trust Society", In: Habisch, A., Jonker, J., Wegner, M., and Schmidpeter, R. (Eds.). Corporate social responsibility across Europe, Springer Science \& Business Media: Berlin, pp. 13-22.

Kouchtch, S. P. and Afanasiev, A. A. (2004), Marketing perspectives of inter-firm networks: The Russian practice (No. 124). Graduate School of Management, St. Petersburg State University.

Laari-Salmela, S., Mainela, T., and Puhakka, V. (2015), "Beyond network pictures: Situational strategizing in network context", Industrial Marketing Management, Vol. 45, 117-127.

Langhoff, T. (1997). "The influence of cultural differences on internationalisation processes of firms: An introduction to semiotic and intercultural perspective", in I. Björkman, I. and Forsgren, M. (Eds.), The nature of the international firm. Handelshojskolens Forlag, Copenhagen, pp. 135-164.

Ledeneva, A.V. (1998), Russia's economy of favours: Blat, networking and informal exchange, Cambridge, UK: Cambridge University Press.

Lee, J. W., Abosag, I. and Kwak, J. (2012), "The role of networking and commitment in foreign market entry process: Multinational corporations in the Chinese automobile industry", International Business Review, Vol. 21, No. 1, pp. 27-39.

Leek, S. and Mason, K. (2010), “The utilisation of network pictures to examine a company's employees' perceptions of a supplier relationship", Industrial Marketing Management, Vol. 39, No. 3, pp. 400-412.

Leek, S. Turnbull, P.W. and Naudé, P. (2006), "Classifying relationships across cultures as 
successful and problematic: Theoretical perspectives and managerial implications", Industrial Marketing Management, Vol. 35, No. 7, pp. 892-900.

Leung, K. and Morris, M. (2015), "Values, schemas, and norms in the culture-behavior nexus: A situated dynamics framework", Journal of International Business Studies, Vol. 46, No. 9, pp. 1028-1050.

Lieblich, A., Tuval-Mashiach, R. and Zilber, T. (1998), Narrative research: Reading, analysis, and interpretation. Thousand Oaks, CA: Sage Publications.

Lincoln, Y. S. and Guba, E. G. (1985), Naturalistic Inquiry (Vol. 75), Sage, London.

Lowe, S., Ellis, N. and Purchase, S. (2008), "Rethinking language in IMP research: Networking processes in other words", Scandinavian Journal of Management, Vol. 24, No. 4, pp. 295307.

Lämsä (2010), "Leadership Styles and Decision-making in Finnish and Swedish Organizations", Review of International Comparative Management, Vol. 11, No. 1, pp. 139- 149.

Mattsson, L.G. (2002), "Dynamics of Markets: How 'Actor-Network Theory' and 'Markets-asNetworks' Can Learn From Each Other", Paper presented at the Nordic Workshop on Interorganizational Studies, Kolding, August 2002.

Mattsson, L. G., Corsaro, D. and Ramos, C. (2015), "Sense-making in business markets - The interplay between cognition, action and outcomes", Industrial Marketing Management, Vol. 48, pp. 4-11.

Mattsson, L. G. and Salmi, A. (2013), "The changing role of personal networks during Russian transformation: challenges for Russian management", Journal of Business \& Industrial Marketing, Vol. 28, No. 3, pp. 190-200.

May, R. C., Puffer, S. M. and McCarthy, D. J. (2005), "Transferring management knowledge to Russia: A culturally based approach", The Academy of Management Executive, Vol. 19, No. 2, pp. 24-35.

McDermott, G.A. and Corredoira, R.A. (2010), "Network composition, collaborative ties, and upgrading in emerging-market firms: Lessons from the Argentine autoparts sector", Journal of International Business Studies, Vol. 41, pp. 308-329.

Michailova, S. and Worm, V. (2003), "Personal Networking in Russia and China: Blat and Guanxi”, European Management Journal, Vol. 21. No. 4. pp. 509-519. 
Mitrega, M., Forkmann, S., Ramos, C., and Henneberg, S. C. (2012), "Networking capability in business relationships - Concept and scale development," Industrial Marketing Management, Vol. 41 No. 5 pp. 739-751.

Möller, K. and Svahn, S. (2004), "Crossing east-west boundaries: Knowledge sharing in intercultural business networks", Industrial Marketing Management, Vol. 33, No. 3, pp. 219228.

Möller, K. and Rajala, A. (2007), "Rise of strategic nets - New modes of value creation", Industrial Marketing Management, Vol. 36, No. 7, pp. 895-908.

Newton, K. (2001), “Trust, social capital, civil society, and democracy", International Political Science Review, Vol. 22, No. 2, pp. 201-214.s[ep?

Osetrova, E. (2011), "Sluhi v sovremennoj sociokul'turnoj srede: istoriograficheskij obzor", Antropologicheskij Forum, No. 15, pp. 55-82.

Parker, S.C. (2008), "The economics of formal business networks", Journal of Business Venturing, Vol. 23, No. 6, pp. 627-640.sêp?

Pesmen, D. (2000), Russia and soul: an exploration, Cornell University Press, Ithaca, NY.

Pittaway, L., Robertson, M., Munir, K., Denyer, D. and Neely, A. (2004), "Networking and innovation: a systematic review of the evidence", International Journal of Management Reviews, Vol. 5, Nos. 3-4, pp. 137-168.

Puffer, S. M. and McCarthy, D. J. (2011), "Two decades of Russian business and management research: An institutional theory perspective", The Academy of Management Perspectives, Vol. 25, No. 2, pp. 21-36.

Radaev, V. (2013), "Market power and relational conflicts in Russian retailing", Journal of Business \& Industrial Marketing, Vol. 28, No. 3, pp. 167-177.

Rasmussen, E.S. and Madsen, T.K. (2001), "The Founding of the Born Global Company in Denmark and Australia: Sensemaking and Networking”, Asia Pacific Journal of Marketing and Logistics, Vol. 13, No. 3, pp. 75-107.

Ritter, T. (1999), "The networking company: antecedents for coping with relationships and networks effectively", Industrial Marketing Management, Vol. 28, No. 5, pp. 467-479.

Ritter, T., Wilkinson, I. F. and Johnston, W. J. (2002), "Measuring network competence: some 
international evidence", Journal of Business \& Industrial Marketing, Vol. 17, Nos. 2/3, pp. $119-138$.

Ritter, T., Wilkinson, I.F. and Johnston, W.J. (2004), "Managing in complex business networks", Industrial Marketing Management, Vol. 33, No. 3, pp. 175-183.

Salmi, A. (2000), "Entry into turbulent business networks: The case of a Western company on the Estonian market", European Journal of Marketing, Vol. 34, Nos. 11/12, pp. 1374-1390 istep?

Sasi, V. and Arenius, P. (2008), "International new ventures and social networks: Advantage or liability?”, European Management Journal, Vol. 26, No. 6, pp. 400-411.

Schweizer, R. (2012), "The internationalization process of SMEs: A muddling-through process", Journal of Business Research, Vol. 65, No. 6, pp. 745-751.

Shinkle, G. A., Kriauciunas, A. P. and Hundley, G. (2013), "Why pure strategies may be wrong for transition economy firms", Strategic Management Journal, Vol. 34, No. 10, pp. 12441254.

Siggelkow, N. (2007), "Persuasion with case studies", Academy of Management Journal, Vol. 50, No. 1, pp. 20-24.

Spradley, J. P. (1979), The ethnographic interview, Holt, Rinehart and Winston, New York, NY.

Terziovski, M. (2003), "The relationship between networking practices and business excellence: a study of small to medium enterprises (SMEs)", Measuring Business Excellence, Vol. 7, No. 2, pp. 78-92.

Thorelli, H. B. (1986), "Networks: Between markets and hierarchies", Strategic Management Journal, Vol. 7, pp. 37-51.

Tidström, A. and Hagberg-Anderson, Å. (2012), "Critical events in time and space when cooperation turns into competition in business relationships", Industrial Marketing Management, Vol. 41, No. 2, pp. 333-343.

Torkkeli, L., Puumalainen, K., Saarenketo, S. and Kuivalainen, O. (2012), "The effect of network competence and environmental hostility on the internationalization of SMEs", Journal of International Entrepreneurship, Vol. 10, No. 1, pp. 25-49.

Trompenaars, F. (1993), Riding the Waves of Culture: Understanding Cultural Diversity in Business, Economist Books, London. 
Turnbull, P., Ford, D. and Cunningham, M. (1996), "Interaction, relationships and networks in business markets: an evolving perspective", Journal of Business \& Industrial Marketing, Vol. 11 , Nos. 3/4, pp. 44-62.

Tähtinen, J. and Blois, K. (2011), "The involvement and influence of emotions in problematic business relationships”, Industrial Marketing Management, Vol. 40, No. 6, pp. 907-918.

Voldnes, G., Grønhaug, K. and Nilssen, F. (2012), "Satisfaction in buyer-seller relationshipsInfluence of cultural differences", Industrial Marketing Management, Vol. 41, No. 7, pp. 1081-1093.

Watson, J. 2007. Modeling the relationship between networking and firm performance. Journal of Business Venturing, 22(6): 852-974.

Weck, M. and Ivanova, M. (2013), "The importance of cultural adaptation for the trust development within business relationships", Journal of Business \& Industrial Marketing, Vol. 28, No. 3, pp. 210-220.

Weick, K. E. (1995), Sensemaking in organizations, Sage, Thousand Oaks, CA.

Weick, K.E., Sutcliffe, K.M. and Obstfeld, D. (2005), "Organizing and the process of sensemaking”, Organization Science, Vol. 16 No. 4, pp. 409-421.

Wierzbicka, A. (2002), "Russian cultural scripts: The Theory of Cultural Scripts and Its Applications", Ethos, vol. 30, no. 4, pp. 401-432.

Wilkinson, I. and Young, L. (2002), "On cooperating: firms, relations and networks", Journal of Business Research, Vol. 55, No. 2, pp. 123-132.

Williams, J.D., Han, S.-L. and Qualls, W.J. (1998), “A conceptual model and study of crosscultural business relationships", Journal of Business Research, Vol. 42, No. 2, pp. 135-143.

Woodside, A.G. and Wilson, E.J. (2003), "Case study research methods for theory building", Journal of Business \& Industrial Marketing, Vol. 18, Nos. 6/7, pp. 493-508.

Yin, R.K. (2009). Case Study Research, 4. ed. California: Sage.

Öberg, C. (2010), "What happened with the grandiose plans? Strategic plans and network realities in B2B interaction", Industrial Marketing Management, Vol. 36, No. 6, pp. 926-940. 